iii. * But while they stood and wept, and called by name / Upon the dead, amidst them came a man | With raiment rent, and haggard face and wan. W. Morris, The Earthly Paradise, Crasus, LXV.

I stood and stared at myself in the glass. Rid. Haggard, She, Ch. I.

I have stood and watched it (sc. Moulsey lock) sometimes, when you could not see any water at all. Jerome, Three Men in a Boat, Ch. VIl, 74.

She merely chucked me a 'Good night' over her shoulder and went on playing. I couldn't realize it for a minute. I simply stood and stared. Keble Howard, One of the Family, I, Ch. III, 47.

** I stood looking at the basket quite lost in the magnitude of my trust. Dick., Bleak House, Ch. VI, 43.

We saw a tall gentleman standing looking at us intently and solemnly. Sweet, Old Chapel.

Note $a)$ It is hardly necessary to observe that these verbs may also be followed by an infinitive with final to.

I revisited each of the old haunts ... The old beech stump on which I sate to read letters from home. Lylton, Caxtons, II, Ch. V, 53.

$\beta$ ) Of particular interest is the use of to stand before to + infinitive to express likelihood.

If the taxation of food was in itself defensible, Ireland stood most to gain by it. Westm. Gaz., No. 6129, 1 c.

It is a fact which cannot be blinked that Austria stands to lose by the establishment of a Balkan Confederation on her southern frontier. ib., No. $6165,1 b$.

Germany seems to stand to make more enemies by her successes than by her failures. The New Statesman, No. 115, 241 b.

(To be continued).

Amsterdam.

H. Poutsma.

\title{
OP VERKENNING.
}

I.

\section{A Shropshire Lad.}

Niet alleen in Nederland is het aantal poëten legio; men telt ze in de Engels-sprekende landen bij bosjes, en de bundels gedichten die ze van tijd tot tijd - 'n gestadige Mississippi van verzen - het licht doen zien, renderen nog minder dan hier te lande 'n beknopte Engelse schoolgrammatica. De regel is evenwel dat 'n gedicht pas in zo'n bundel verschiint, nadat eerst een of ander tijdschrift zich er over heeft ontfermd, en de meeste Engelse tijdschriften betalen voor poëzie 'n honorarium, dat aan Hollandse dichters, die zich meestal moeten tevreden stellen met le bonheur de se voir imprimé, fabelachtig moet voorkomen.

Ziedaar in hoofdzaak het verschil; overigens is er schier niets als overeenkomst . . . Zonderling, - als er 'n kindje geboren wordt, dan blijkt terstond of het dood is dan wel leeft, en in 't laatste geval al heel gaww of 't 'n blijvertje zal zijn of niet. Maar op 't punt van gedichten snijdt de kritiek in Engeland zich al even vaak en even erg in de vingers als hier. En da's óók zonderling, - kritizeren is toch geen luk-rake planeetlezerij? Is 't zó lastig, 
de al of niet aanwezigheid van wat men ,leven" noemt, in 'n gedicht te konstateren? We spreken nu niet over het toevallig uiterlik van het wicht zeer zelden „ideaal” -, maar over de vraag, of het behoorlik schopt met armen en benen...

Ik herinner me, eens aan 'n omstreeks vijf-en-dertigjarige "headmaster" M. A. Oxon - in 1901 te hebben gevraagd, wie z. i. de beste levende Engelse dichter was, nu Tennyson, Browning en Arnold tot hun vaderen waren verzameld. Na enig bezinnen noemde hij - Lewis Morris. Swinburne en Meredith leefden toen nog, en vijf jaren te voren was $A$ Shropshire Lad verschenen. Over dit bundeltje hoorde ik toentertijd niemand praten, en 't is mij onbekend of 't wel ooit het onderwerp is geweest van ' $n$ bespreking waaraan Jantje van Leiden geen deel had. Tegenwoordig wordt er váák op gezinspeeld, - bij 't beoordelen van ànder dichtwerk - en in letterkundige kringen hoort men er zelden anders van gewagen dan op de gedempte toon van stil ontzag. En de herdrukken volgen elkaar geregeld op, in goedkope en met smaak uitgevoerde edities (1 shill. net, Grant Richards.). Ook heeft het komponisten geïnspireerd. Leven zit er dus wel in.

Wat bewaart 'n dichtwerk voor vergetelheid? Afmeting?! - Hoe langer 'n gedicht, des te gauwer in 't rommelhoekje der misschien geprezenen, maar nimmer gelezenen. - De aanwezigheid van "mooie brokken" en van „jewels five words long"? - Ik heb er nooit iets van gemerkt: en 'n gedicht is toch geen ontbijtkoek, die smakelik wordt gemaakt door sporadiese stukjes gember! En naderhand komt men zo'n juweel wel 'ns in 't werk van anderen tegen, al of niet tussen aanhalingstekens, - maar men herinnert zich de vindplaats niet meer. - Gedachtevlucht? - Die is opzichzelf onvoldoende, en wordt trouwens lang niet altijd op prijs gesteld; tegenwoordig zit het weer in de lucht, te glimlachen over "kosmiese" poëzie, mitsgaders de „immensities", de „moral uplift", en 's dichters „message”. - 't Vertolken van de "geest des tijds" heeft, uit den aard der zaak, ook maar 'n betrekkelike waarde. De gewone kunstlievende mens leest gedichten uit vroeger tijd niet om te weten te komen, hoe de mensen van 'n speciale eeuw voelden en dachten, maar alleen om te genieten van wat hij nu nog mooi kan vinden. En in de regel zal dit "mooivinden", afgezien van de verklankte gevoelens, bepaald worden door de struktuur van 't gedicht; door 't bewust of onbewust waarderen van wat uit ' $n$ kunstenaarsoogpunt "af" is. En nu is er in de poëzie allerlei struktuur mogelik; sommige gedichten zullen in dit opzicht herinneren aan bouwwerken, andere aan gobelins, aan schilderijen, aan sonates, fuga's, gedreven metaal, juwelen, - of, eenvoudiger, aan simpele meetkunstige figuren, 'n kegel, 'n driehoek, 'n enkele flauw-gebogen lijn - maar 'n zekere struktuur, van welke aard ook, zal steeds kunnen worden aangewezen.

A Shropshire Lad is 'n rijmsnoer, bestaande uit 63 kleine, zeer geacheveerde gedichten. De rangschikking komt me vrij willekeurig voor, met uitzondering dan van nummers 1, 62 en 63. Het eerste "strikes the keynote"; nr. 62 is 'n vernuftig verweer, dat de dichter richt tot de niet-weinige lezers, die iets ziekeliks zullen vinden in z'n steeds verwijlen bij 'n beperkt aantal somber- 
stemmende levensaspekten; 't laatste is 'n soort van opdracht van de bundel aan "luckless lads" door iemand die, hij moge als jonge man veel ongelukkigs hebben doorgemaakt, ten tijde der publikatie zes of zeven en dertig jaar was. Vermoedelik waren de gedichtjes toen al niet kersvers; de vorm van elk is zo "af", de uitdrukkingswijze is zo „eigen”, er zijn zó weinig bepaald zwakke - litterair-zwakke - plaatsen, dat men veilig kan aannemen, dat alles lang in portefeuille gebleven is, en telkens en telkens is herzien en gevijld en omgewerkt door iemand, die er 'n zwaarmoedig behagen in schepte, zich telkens weer te verdiepen in het leed, de aandoeningen, teleurstellingen en ontgochelingen van $z$ 'n sentimentele tijd, toen hij van twintig tot drie en twintig jaar was.

Ik sprak daar vari 'n „eigen" uitdrukkingswijze. We kunnen veilig konstateren, dat A. E. Housman die heeft, al ontmoeten we wel 'ns dingen, die ons niet onbekend voorkomen .... .

Ah, life, what is it but a flower?

Why must true lovers sigh? (V)

is te verklaren uit de wens, de niet-oorspronkelike en sedert eeuwen zich openbarende elementen van jongelings-sentimentaliteit psychologies te karakteriseren. De eruditie van de „Professor of Latin” der Londense Universiteit komt bewust naar voren in nummer X (March):

The Sun at noon to higher air,

Unharnessing the silver Pair

That late before his chariot swam,

Rides on the gold wool of the Ram.

Maar, - is het heus wel wenselik dat 'n gedicht zij "de allerindividueelste uitdrukking van de allerindividueelste emotie"? Berust niet de levensvatbaarheid van 'n gedicht op 'n. geslaagd vergelijk, 'n compromis tussen traditie en oorspronkelikheid, tussen individueel-voelen-en-uitdrukken en 't vertolken van anders tot stomheid gedoemde gevoelens van bredere groepen? Er zijn dingen genoeg in $A$ Shropshire Lad, waarvan men de grond-idee ook in andere dichters kan vinden, en die evenwel toch "nieuw" aandoen.

Bij Herrick b.v. vinden we

\section{To Silvia.}

I am holy while I stand

Circum-crossed by thy pure hand:

But when that is gone, again

I, as others, am profane.

Dit wordt bij Housman (XVIII):

Oh, when I was in love with you, Then I was clean and brave,

And miles around the wonder grew How well did I behave.

And now the fancy passes by, And nothing will remain, And miles around they'll say that I Am quite myself again. 
Wie hier nu 't "mooist" is, Herrick of Housman, valt waarschijnlik nooit uit te maken. Maar zeer velen zullen kunnen verklaren, dat van die twee dichters de moderne, de rauwere, de meest onmiddellike uitdrukking heeft gegeven aan 'n zielstoestand, door zeer velen doorleefd; m.a.w. dat Housman niet bij $z$ 'n zeventiende-eeuwse voorganger in oorspronkelikheid en zeggenskracht achterstaat, en als modern mens voor de moderne mens meer betekent dan de precieuze 1 ) Herrick.

Ben ik misschien zoeven iets te ver gegaan door te gewagen van vertolking van sentimentele jongelingstijd? 't Is ' $n$ feit dat de melancholiek-esthetiese aandoening van weemoed-om-zijnszelfswil, de stemming van "Il pleut doucement sur la ville", in $A$ Shropshire Lad niet wordt aangetroffen. De regen schittert zelfs door algehele afwezigheid, en toch is vooral de motregen 'n. onontbeerlik en hooglik gewaardeerd bestanddeel van ' $n$ melancholiek dichter z'n poëtiese inventaris. De bekommernissen van de Shropshire yeoman zijn alle echt, of tenminste echt voor hem: $z$ 'n liefste wil niets van 'm weten (V, XIII, XIV enz.); hij wordt gekweld door 't besef van 't zelfzuchtig. element in de liefde van man tot meisje (VI); door de overweging van 's levens kortheid en doelloosheid (VII); 'n vriend van hem is broedermoordenaar (VIII); „misdadigers", die werkelik niet slechter zijn dan hij, werden en worden opgehangen (IX); menig ongelukkig minnaar heeft 't zichzelf gedaan (XVI); wat belet hem het ook te doen? (XVII). Hij sterft niet, en anderen, flinke, brave borsten, zelfs athleten, worden jong weggerukt (XIX, XXIII, LIV); z'n meisje is dood (XXI); "he cheers a dead man's sweetheart" (XXV, XXVI, XXVII); z'n persoonlikheid is ten prooi aan innerlike verscheuring (XXVIII, XXX); hij moet weg van z'n meisje (XXXVI); hij heeft heimwee naar Shropshire (XXXVIII, XXXIX, XL, XLI, LI, LII); „die z'n medemensen te lief heeft wordt gekruisigd" (XLVII); hij voelt zich in opstand tegen aarde en hemel, "which ail from the prime foundation" (XLVIII).

Is er niet iets, dat hem met het leven verzoenen kan? Zeker! Er zijn bloeiende kerseboomgaarden in Shropshire - maar's mensen leven is eigenlik te kort om er al 't moois af te kijken; laat daarom de lentetijd niet ongebruikt (II).

Loveliest of trees, the cherry now

Is hung with bloom along the bough,

And stands about the woodland ride

Wearing white for Eastertide.

Now, of my threescore years and ten

Twenty will not come again,

And take from seventy springs a score,

It only leaves me fifty more.

And since to look at things in bloom

Fifty springs are little room,

About the woodlands I will go

To see the cherry hung with snow.

1) Ik gebruik dit woord zonder de minste geringschatting. 
't Is niet alleen "carpe diem", 't is „carpe horam" bij Housman. Er is zoveel te zien op de wereld: slaap niet te lang! (IV).

Up, lad: thews that lie and cumber Sunlit pallets never thrive;

Morns abed and daylight slumber Were not meant for man alive.

Clay is still, but blood's a rover;

Breath's a ware that will not keep.

Up, lad: when the journey's over There 'll be time enough to sleep.

Schijnt het rijk der fantasie mooier? Laat je niet door schijn verschalken tot domheden (XX). "Life is real”, zegt Housman Longfellow na, maar aangezien 't graf wèl "its goal" is, laten we elkaar nù bijstaan:

From far, from eve and morning

And yon twelve-winded sky,

The stuff of life to knit me

Blew hither: here am I.

Now - for a breath I tarry

Nor yet disperse apart -

Take my hand quick and tell me,

What have you in your heart.

Speak now, and I will answer;

How shall I help you, say;

Ere to the wind's twelve quarters

1 take my endless way. (XXXII).

En wie tot zulk een zich-nuttig-maken de kracht mist, laat hem soldaat worden: veel beter dàt dan ' $n$ verslappend leven van nietsdoen en achternalopen van meisjes, die niets om je geven (I, III, XXXIV, XXXV). En deug je nergens, nergens voor - heb dan de moed er 'n eind aan te maken (XLIV, XLV). Trouwens - eenmaal komt het einde toch, en daarmee 'n eind aan al onze kommer en verdriet:

The gale, it plies the saplings double,

It blows so hard, 't will soon be gone:

To-day the Roman and his trouble

Are ashes under Uricon. (XXXI).

En intussen: zet de tanden op elkaar: neem 'n voorbeeld aan die Griekse man van steen, dat standbeeld in 't British Museum.

Still he stood and eyed me hard,

An earnest and a grave regard:

'What, lad, drooping with your lot?

I too would be where I am not... (LI).

Wees niet bang voor de toekomst: zo stilletjes-aan raakt men aan narigheid gewend en onze schouders dragen beter: 
$\ldots$ if as a lad grows older

The troubles he bears are more,

He carries his griefs on a shoulder

That handselled them long before. $(\mathrm{L})$.

En de dood - is niets. Niet bang zijn!

Oh never fear, man, nought's to dread,

Look not left nor right:

In all the endless road you tread

There's nothing but the night. (LX).

Housman, professor of Latin biedt ons dezelfde troost als Lucretius.

Hij heeft echter nog iets "up his sleeve". We leven niet voor niets in het tijdperk van vaccine en serum. Klaagt men over 'n ziekelik element in z'n bundel, Housman zegt, dat dit ziekelike misschien zeer bevorderlik zal zijn voor 's lezers gezondheid: Denk 'ns aan Mithridates. Die nam ook vergif in, bij kleine beetjes, maakte zich zodoende immuun, en kon ten laatste niet meer dood! (LXII). Zo ook met mijn verzen: ze wekken aandoeningen, meestal onbehaaglike aandoeningen; ze spreken vaak over de nietigheid des levens en de zekerheid des doods. Welnu, langzamerhand raken m'n lezers in die gevoels- en gedachtesfeer zo zeer thuis, dat, wanneer hunzelf in 't werkelike leven iets zeer pijnliks gebeurt, de aandoening hun bekend voorkomt, en de persoon gelaten $z$ 'n weg kan blijven vervolgen. Want het is niet de hevigheid van de schok die dodelik is, maar 't onvoorbereid-zijn van wie de schok treft. - Vernuftig gevonden.

En hiermede zeggen wij $A$ Shropshire Lad vaarwel. We hadden meer kunnen aanstippen, de diktie, die al wijst op wat met Gibson en Masefield tot volle bloei zou komen: het besef dat dichtertaal veredelde, desnoods onveredelde, maar steeds hartstochtelik vibrerende spreektaal is, en geen schrijftaalop-stelten; alsook 't imperialisme, dat zich bij hem vertoont vóór hij van Kipling kan hebben geweten; verder Housmans voorliefde voor simpele, oude versvormen, met korte, maar nooit onbeduidende regels. Maar de ruimte, die Neophilologus tot zijn beschikking heeft, is nu eenmaal beperkt.

Zaandam.

WILLEM VAN DOORN.

\section{VARIA. \\ LES PRÉCIEUSES DANS CHARLES D'ORLÉANS. Rondeau 105.}

Aussi bien laides que belles

Contrefont les dangereuses

Et souvent les précieuses;

En ont les manières telles.

Pareillement les pucelles

Deviennent tantost honteuses;

Aussi bien laides que belles

Poésies complètes de Charles d'Orléans, revues sur les ms avec Préface, notes et glossaire par Charles d'Héricault, Tome I. E. Flammarion, Paris, 1896.
Contrefont les dangereuses.

Les vieilles font les nouvelles

En parolles gracieuses

Et accointances joyeuses;

C'est la condicion d'elles,

Aussi bien laides que belles. 